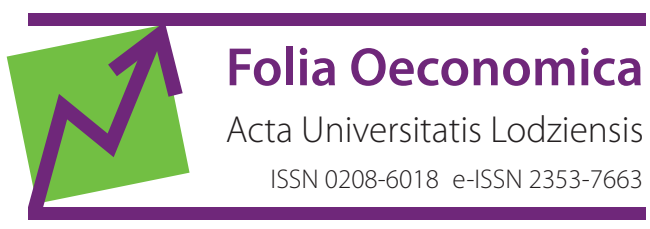

www.czasopisma.uni.lodz.pl/foe/

4(343) 2019

DOI: http://dx.doi.org/10.18778/0208-6018.343.07

\title{
Liwiusz Wojciechowski
}

Cracow University of Economics, Faculty of Economics and International Relations

Department of Foreign Trade, liwiusz.w@o2.pl

\section{Kamil Makieła}

Cracow University of Economics, Faculty of Management

Department of Econometrics and Operational Research, kamil.makiela@uek.krakow.pl

\section{Determinants of Foreign Direct Investments in the Visegrad Group Countries ${ }^{1}$}

\begin{abstract}
The purpose of this paper is to investigate determinants of foreign direct investments (FDI) in the Visegrad Group countries. The theory indicates that FDI are mainly driven by market and efficiency seeking motives. Foreign investors are looking for a productive and relatively low-cost business environment, which leads us to the assumption that productivity is one of key drivers of foreign capital. In order to verify this, we formulate a model based on a system of two equations: one for production to capture productivity and one for FDI to assess the influence of productivity on FDI. For robustness check, a number of macroeconomic and institutional factors are also considered. The study is conducted using a panel of 13 NACE industry sectors of the Visegrad Group countries in 2004-2013. The results indicate a positive, significant relationship between FDI and productivity as well as that market size, labour quality (and quantity), R\&D expenditures and price changes over time are relevant FDI determinants at an industry level.
\end{abstract}

Keywords: Foreign Direct Investment, Visegrad countries, Bayesian model averaging JEL: F21, O47, C11

1 Research financed by the National Science Centre: project title "Foreign Direct Investments and Productivity. Empirical Verification of the Theoretical Model of Conditional Interdependencies. The Case of V4 Countries" No 2015/17/N/HS4/01528. 


\section{Introduction}

There is a number of explanations suggested in the literature as to what factors influence capital flow between economies; see e.g.: Estrin and Beven (2004), Wach and Wojciechowski (2016) for an overview. Based on the aforementioned, it can be concluded that investment decisions regarding Foreign Direct Investments (FDI hereafter) and their allocations are determined, to a large extent, by potential advantages and benefits from internalisation. The choice of the host economy is also largely determined by its enterprise environment. It is important to emphasise that FDI are not only a simple transfer of financial capital and that FDI can be highly volatile, much more than e.g.: consumption. However, one can distinguish certain factors that are responsible for shaping their size and characteristics. Firstly, there are the so-called push factors, which relate to possibilities of doing business in the source (i.e. investor's) country. Secondly, there are the so-called pull factors driven by the situation in the host (i.e. potentially interesting to invest in) country. Thirdly, FDI may either be defensive or offensive. Offensive investments are made with the intention of gaining new markets, while defensive ones are made to protect the market position (Yannopoulos, 1990; 2011; Karaszewski, 2004).

The existing empirical literature on bi-directional causation between FDI and economic growth is scarce, not to mention the fact that the subject is mostly dealt with at the macro level (Chowdhury, Mavyrotas, 2005; Siddique et al., 2017). That is why, although decisions about undertaking investments depend on several factors, it should be noted that (i) capital and labour endowments in the host country play a significant role in enhancing productivity (and thus production growth), and that (ii) the impact of these factors can differ significantly between industries and across time. Determinants of FDI should be investigated by taking into account the above-mentioned and in doing so, there are three aspects of the study that should be noted. Firstly, we consider only the V4's inward FDI, i.e. only FDI that came to the V4 countries are considered. Secondly, we are interested in the impact of accumulated FDI presence in the host economy, and thus FDI stock is being analysed. Thirdly, our interest in the V4 economies is not accidental. Since entering the EU, these countries have experienced an unprecedented amount of investments. Furthermore, because the V4 countries are members of the EU there are sufficient data, both in terms of quantity and quality, for us to proceed with FDI analysis at an industry level.

The aim of this study is therefore to investigate determinants of inward FDI stock in the V4 by taking into account the interaction between FDI and economic and productivity growth in a system equation model. In doing so, our contribution is twofold. Firstly, we provide an industry level panel data model that unifies and quantifies the interplay between FDI, economic growth and productivity. We show that explaining determinants of FDI should not be considered as a simple one-equation problem but rather as a system in which FDI influence econom- 
ic growth and productivity gains can influence FDI (via total factor productivity; TFP hereafter). Suffice to say that positive and statistically significant estimates for FDI and TFP parameters in the model would support the hypothesis of a bi-directional relationship between TFP and FDI. Secondly, we use the model to assess what impact TFP has on inward FDI in the V4. Since the empirical literature about FDI and their determinants is inconclusive, we use the Bayesian model averaging technique to mitigate the problem of model uncertainty and find the optimal specification (i.e. a list of robust determinants). This allows us to properly quantify the influence of TFP on FDI, and also to assess what other determinants of many put forward in the literature are meaningful to FDI in the V4 economies.

The paper is organised as follows. Section 2 reviews the literature on the FDI and productivity interaction. Section 3 presents the model and the data gathered for the empirical study. Section 4 summarises empirical findings, while Section 5 concludes with a discussion.

\section{Literature review}

The literature on FDI and their determinants is highly diverse in terms of both theories and empirical results. This kind of model uncertainty (i.e. uncertainty due to the presence of selection bias) has led Eicher, Helfman and Lenkoski (2011) to use Bayesian model averaging in order to obtain robust results. The authors show that some FDI determinants previously suggested in the literature are in fact no longer robust. Furthermore, Antonakakis and Tondl (2015) examine determinants of outward FDI from 4 major OECD countries to 129 developing ones in order to distinguish whether motivation for FDI differs among investors. The authors also use Bayesian model averaging instead of relying on specific theories of FDI determinants and find that no single theory governs the decision on FDI. It is rather a combination of theories. Antonakakis and Tondl (2015) note that although the FDI literature is extensive, there is no study that researches FDI and economic growth by taking into account productivity at an industry level. Also worth mentioning is a recent study of Różański and Socha (2017), who have found that current accumulation of FDI in host countries is a determinant of investments in the future. However, they have not found any relation between profitability of foreign owned entities and a new investment establishment.

With respect to FDI and their determinants, the literature on the expansion of foreign enterprises distinguishes many types of motives that lead to FDI. Wach (2016) points out three main typologies: (i) endogenous/exogenous and proactive/ reactive factors (Albaum, Strandskov, Duerr, 2002); (ii) push and pull motives and 'random chances' (according to the OECD classification); and (iii) Dunning's motives typology (Dunning, Lundgan, 2008). 
The literature on the subject presents different approaches to the semantics of enterprises internationalisation motives (Rymarczyk, 2004; Wach, 2016). Following Wach (2016), various typologies in the literature allow us to divide internationalisation factors into two groups: (i) internationalisation motives, and (ii) internationalisation conditions. In addition, there are many different types of motives for an enterprise to internationalise. Yip and Hult (2012) indicate four groups of factors affecting globalisation processes of enterprises, i.e. (i) market factors, (ii) cost factors, (iii) competitive factors, and (iv) governmental factors.

One of the most frequently quoted typologies that deals with FDI is the typology proposed by Dunning and Lundan (2008). It is a strictly MNE typology, which takes into account the motives of FDI location associated with four groups of behaviours (Dunning, Lundan, 2008): (i) natural resource seekers, (ii) market seekers, (iii) efficiency seekers, and (iv) strategic assets or capabilities seekers.

Wach (2012) expands on the motives for internationalisation proposed by Albaum, Strandskov and Duerr (2002). He takes into account internationalisation factors for an enterprise according to the OECD classification and the entrepreneurial mechanisms known in the theory of entrepreneurship. This idea takes into account simple concepts of identifying market opportunities or dynamic entrepreneurial abilities as well as more cumbersome knowledge-based and charitable enterprise concepts (see Wach, 2012: 75).

Proximity of a given country in both a geographical and cultural sense cannot be neglected when discussing FDI flows. The importance of this factor has been verified in many studies based on the gravity model of trade. Barriers in trade are not only limited to protective policy (e.g.: duties, quotas, subsidies) but also include cultural, linguistic and historical dissimilarities. Table 1 provides a summary of FDI studies and illustrates what factors (from foreign investors' point of view) were found relevant and how (i.e. a positive/negative/neutral impact). Overall, determinants of FDI inflow can be treated as location factors in the host countries which are potentially beneficial for the investors from the source countries (see also Nicolini, Resmini, 2010). One can find many theories that attempt to answer the question why investors move their capital abroad. The presented empirical studies indicate a number of factors determining the involvement of foreign capital in the host country. The one that is the most often mentioned is the size of the target market, which corresponds to the market-seekers motive. However, not only the size of the market is relevant; growth dynamics may also play a significant role. For example, Przybylska (2001) has concluded that the GDP growth rate is a significant factor that attracts FDI in the case of Poland, but not so much in Hungary and the Czech Republic. The quality and cost of labour are also important factors determining the FDI inflow (in line with the efficiency-seekers motive). 


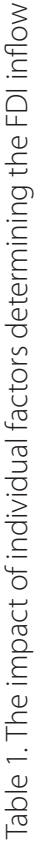

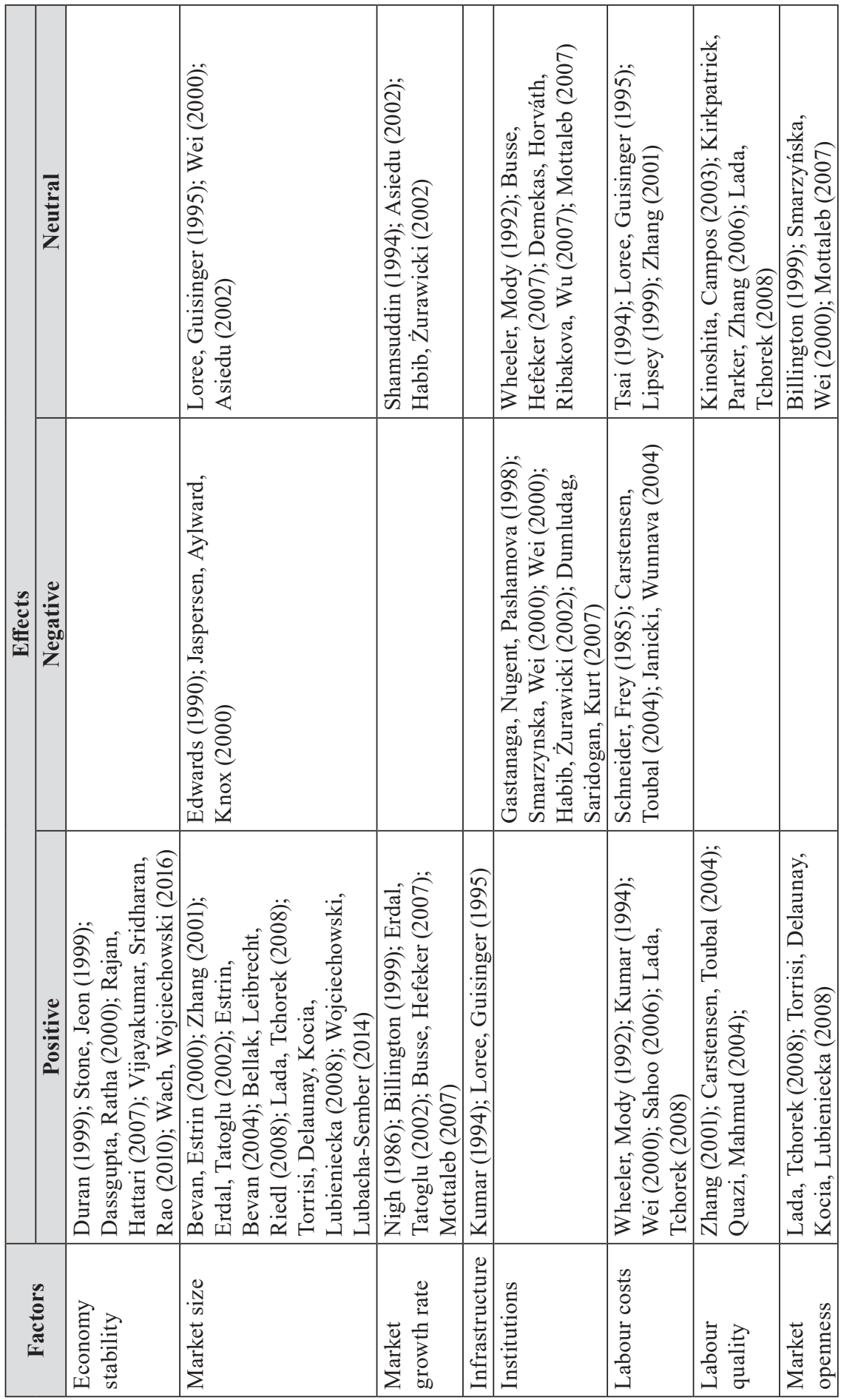




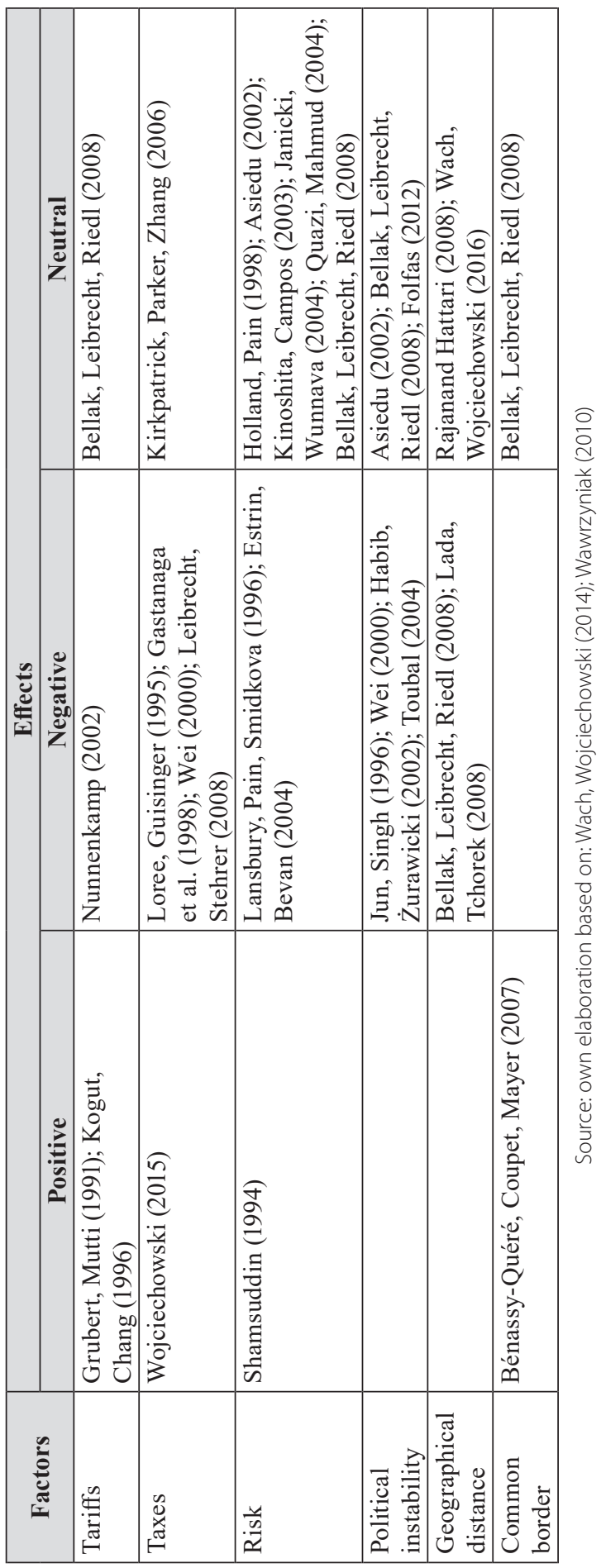

FOE 4(343) 2019 www.czasopisma.uni.lodz.pl/foe/ 
Contemporary studies are rather focused on macro-level data. An industry level breakdown, however, may reveal interesting facts because FDI may affect industries differently. That is, depending on specific conditions (economic/political/institutional), selected factors mentioned in the literature might have a different impact on FDI. Different absorptive capacities of the host country's industries may also have a significant impact on FDI effects and this impact can vary a lot. FDI might differ not so much between economies but rather between industries within an economy. Thus, the need to conduct a study at an industry level.

To sum up, it should be noted that the literature on FDI determinants is very broad and inconclusive. Whether specific factors are found influential for FDI (and how) may not be so much country specific but industry specific. That is why it is important to use a modelling strategy that (i) accounts for such individual industry specific and/or country specific effects and (ii) takes into account modelling uncertainty. In this paper, we show that with information from industry level panel data and an appropriate estimation technique this can be achieved.

\section{Modelling strategy and data}

\subsection{Modelling the interplay between FDI, economic growth and productivity}

The paper puts forward a two-equation system which is to account for interdependencies between the involvement of foreign capital in the host economy and changes in productivity when analysing potential determinants of FDI. Formally, the model we consider can be written as follows:

$$
\left\{\begin{array}{c}
Q_{i j t}=e^{\beta_{0}} g\left(K_{i j t}, L_{i j t}, F D I_{i j t}, G A P_{i j t}\right) e^{\varepsilon_{1, j t}} \\
F D I_{i j t}=h(\theta, X) e^{\varepsilon_{2, j i t}}
\end{array},\right.
$$

where $i, j, t$ are country, industry and time indices respectively. The first equation is an extended production type relation with $Q_{i j t}$ as real production; $K_{i j t}$ as real capital stock, $L_{i j t}$ as the number of people employed and $G A P_{i j t}$ as the labour productivity gap between the EU15 and V4 industries. The random term $\varepsilon_{1, i j t}$ follows the generalised true random effects specification (GTRE; see, e.g.: Tsionas, Kumbhakar, 2014; Filippini, Greene, 2016; Makieła, 2017), which allows us to estimate the industry level TFP used in the second equation as one of explanatory variables for the FDI involvement. The latter equation considers variables suggested in the literature that explain investors' decision making (e.g.: the TFP, R\&D expenditures, market openness, taxation, human capital, and market size). The latter equation 
is linked with the first equation based on theoretical premises. That is, decisions undertaken by foreign investors regarding investment allocation depend, among others, on productivity (TFP) observed in the host industry. Obviously, since a TFP change needs to be observed in order for investors to make a decision, we assume a time lag between FDI and TFP of at least one period. Thus, the system assumes that the current (past) levels of TFP stimulate future (current) FDI and current FDI can influence current economic growth (e.g.: via TFP growth). This linkage has a specific nature described in the deterministic part of the two equations, and thus the stochastic processes of both equations are assumed to be independent. This means that apart from the dependencies described in the deterministic parts, there are no other forms (of stochastic) interaction between these equations. This assumption is justified by the fact that the stochastic processes of both equations arise elsewhere. The first one (i.e. the first equation) describes a process generated within the host economy and is related to the aggregated production function theory. The latter one is of "external" origin and concerns decisions and preferences of foreign investors.

The reader should note that interdependencies between FDI, production and productivity area very broad topic which is beyond the scope of a single study. That is why, in this paper, we focus only on the latter equation of the system. Our aim here is to find relevant industry level determinants of FDI in the V4 while accounting for the interdependency between FDI and productivity. We also investigate the empirical relevance of TFP as a determinant of FDI. Hence, the first equation serves us as a provider of meaningful industry level TFP estimates and its further analysis is beyond the scope of this paper.

Given the literature, we consider two lists of explanatory variables for FDI in the latter equation:

$$
\ln F D I_{i j t}=\theta_{1} x_{1, i j t}+\theta_{2} x_{2, i j t}+\varepsilon_{2, i j t} .
$$

The first list, grouped in the vector $x_{1, i j t}$, represents a short list of discerning, important stimulants of FDI. Here we take the lagged TFP and well-recognised FDI factors such as the target market's size and human capital. The second list, grouped in the vector $x_{2, i j t}$, is made up of determinants that are rather "suggested" in the literature. Here we consider a number of variables of a macroeconomic and institutional nature, potentially determining the involvement of foreign capital in the host country. They include, among others, $R \& D$ expenditures (as a proxy for the economy's innovativeness), economic and political risk, openness, labour costs and taxes (factors determining directly profitability of enterprises)and other business indicators (see Table 2, Section 3.2).

In order to mitigate the problem of model uncertainty, we use Bayesian model averaging (BMA). Potential factors determining FDI accumulation have been 
selected based on the studies listed in Section 2 and the Dunning eclectic theory. The final list of robust determinants is derived using BMA, which limits the selection bias. This allows us to investigate whether productivity, measured by TFP, is indeed one of key factors determining FDI accumulation in the host economy and what other factors put forward in the literature are robust FDI determinants for the Visegrad countries.

It should be noted that model uncertainty is treated here as uncertainty about the list of explanatory variables in $x_{2, i j t}$. We use BMA because of (i) a large number of potential regressors, and therefore a great deal of their possible combinations, (ii) the usefulness of these methods in such cases (i.e. cases when the literature does not provide an exact list of explanatory variables), (iii) development of appropriate numerical methods in recent years, (iv) more 'robust' results (in terms of appropriate variable selection), and (v) increasing popularity of these tools in research on economic growth and conditional convergence (Sala-i-Martin, Doppelhofer, Miller, 2004; Próchniak, Witkowski, 2012). Details regarding BMA used in the study can be found in the appendix.

\section{Industry level data for FDI analysis}

Taking into account the availability and comparability of statistical data for individual industries and numerous data deficiencies (e.g.: missing data or their different measurement standards), a panel of 13 industry sectors of the NACE national economy in the years 2004-2013 has been considered in the analysis. The choice of the year 2004 is also not accidental due to the accession of the Visegrad Group countries to the European Union. This has essentially influenced (among other things) the flow of capital to these countries. The last year for our dataset is 2013 due to the availability of reliable data on FDI for Hungary at the time of the analysis. To sum up, selection of the data presented in Table 2 is a derivative of (i) data availability, (ii) economic theory of FDI, (iii) the empirical literature on the subject, and (iv) discussions with government representatives and the scientific and business community at the Annual Investment Meeting 2017, which took place in the United Arab Emirates on 2-4.04.2017².

2 The first author personally participated in this meeting, its participants served as an expert panel. 


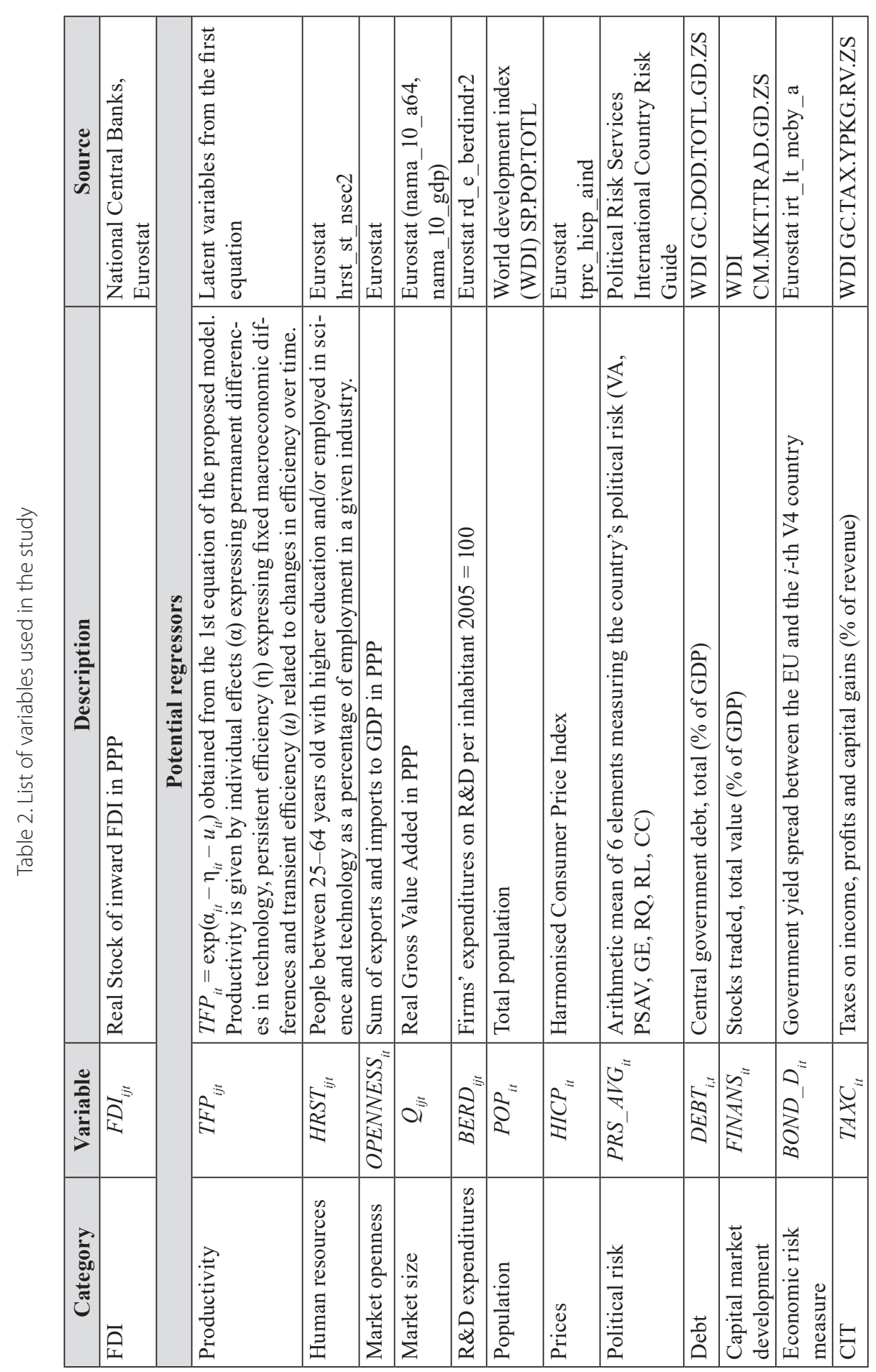




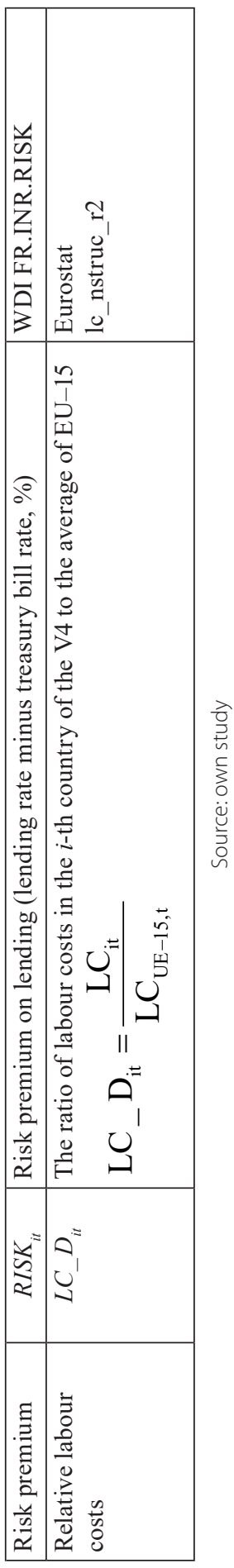

www.czasopisma.uni.lodz.pl/foe/ FOE 4(343) 2019 


\section{Findings}

The results of BMA are provided in Table 3, which lists all potential explanatory variables considered in the study (the first column) with their respective parameters estimates. We turn our attention to column 5, which contains information on the posterior inclusion probability (PIP), i.e. the probability that a given variable should be included in the final, optimal specification. We can note that a number of variables have PIP way above $50 \%$, which indicates their relevance in explaining FDI. This is confirmed by standard regression statistics in columns 2-4 and 6 . In particular, for variables with PIP above $50 \%$, we see that $95 \%$ confidence intervals of their respective parameters are strictly positive (or negative as in the case of the parameter for BERD).

The results indicate that several factors determine accumulation of FDI, with the first-lag TFP being a major one. The estimate of TFP parameter is relatively high indicating a large influence of TFP on decisions about FDI allocation. The increase in $T F P_{(t-1)}$ of one percentage point (p.p.) leads to an increase in FDI of $0.673 \%$. Moreover, this estimate is statistically significant with $t$ ratio equal to 2.56 . It should be noted that although Table 3 presents only the final results on TFP, for robustness check, we have also considered other forms of TFP calculation and different TFP lags ${ }^{3}$. The obtained results are comparable regardless of this choice while TFP $(t-1)$ gives the best model fit. Moreover, since TFP lag (1, 2 or 3 ) expresses delays associated with investors' decision-making on capital allocation to foreign countries, it seems that investors make decisions mostly based on observed productivity in the previous year.

Market size, expressed via $Q_{(t-1)}$, is the most relevant explanatory variable with the highest and most statistically significant parameter estimate. The increase in market size of one p.p. leads to an increase in FDI of $0.84 \%$. This suggests a strong presence of the market seekers motive and indicates that foreign investors are interested in large, high-absorptive capacity industries (Wojciechowski, Lubacha-Sember, 2014). The variable describing the quality of human capital in a given industry (HRST) also relates positively and significantly to FDI. The increase in HRST of one percent increases FDI by $0.154 \%$. These results are consistent with the view that foreign investors seek highly-qualified employees, especially in respect to investments undertaken in high and medium-high technology industries. It is worth noting that the relative level of human capital in the investor's country is reported to be positively and closely related to the size of FDI activity (Cieślik, 2017).

3 We have considered up to a third-lag TFP in two different scenarios of TFP calculation. In the first scenario, we have taken TFP only as an individual effect $\exp \left(\alpha_{i i}\right)$; see (1). In the other scenario, we have assumed that TFP is a sum of inefficiencies: $\exp \left(-\eta_{i t}-u_{i t}\right)$. 
Table 3. The results of the estimation for the latter equation explaining the reason for the accumulation of FDI

\begin{tabular}{|l|c|c|c|c|c|c|}
\hline $\begin{array}{c}\text { Explanatory } \\
\text { variable }\end{array}$ & $\begin{array}{c}\text { Parameter } \\
\text { estimate }\end{array}$ & Error & $\boldsymbol{t}$ ratio & PIP & \multicolumn{2}{c|}{$\begin{array}{c}\text { 95\% confidence } \\
\text { interval }\end{array}$} \\
\hline Const. & -1.840 & 3.036 & -0.61 & $100 \%$ & -4.876 & 1.195 \\
\hline$T F P(t-1)$ & 0.673 & 0.263 & 2.56 & $100 \%$ & 0.410 & 0.936 \\
\hline$Q(t-1)$ & 0.840 & 0.111 & 7.59 & $100 \%$ & 0.729 & 0.951 \\
\hline HRST & 0.150 & 0.030 & 5.05 & $100 \%$ & 0.120 & 0.180 \\
\hline BERD & -0.011 & 0.006 & -1.99 & $80 \%$ & -0.016 & -0.005 \\
\hline POP & 0.018 & 0.010 & 1.77 & $85 \%$ & 0.008 & 0.028 \\
\hline HICP & 0.017 & 0.010 & 1.51 & $79 \%$ & 0.005 & 0.026 \\
\hline PRS_AVG & 0.006 & 2.365 & 0.00 & $13 \%$ & -2.359 & 2.371 \\
\hline OPENNESS & 0.004 & 2.295 & 0.00 & $12 \%$ & -2.291 & 2.299 \\
\hline FINANS & 0.017 & 0.093 & 0.19 & $9 \%$ & -0.076 & 0.110 \\
\hline DEBT & 0.009 & 0.170 & 0.05 & $8 \%$ & -0.161 & 0.179 \\
\hline BOND_D & 0.001 & 0.016 & 0.06 & $8 \%$ & -0.015 & 0.017 \\
\hline LC_D & 0.054 & 0.511 & 0.11 & $7 \%$ & -0.457 & 0.566 \\
\hline TAX_C & 0.001 & 0.008 & 0.09 & $7 \%$ & -0.007 & 0.008 \\
\hline RISK & 0.001 & 0.008 & 0.08 & $7 \%$ & -0.008 & 0.009 \\
\hline
\end{tabular}

Source: authors' calculations, PIP (posteriori inclusion probability) - the probability of including a given variable in the model. In total, the 37 explanatory variables described in Table 2 including TFP lags (up to 3) were used in the estimation, which combined gave over 68.7 billion combinations of models. The final model includes those variables whose inclusion probability was higher than $5 \%$

Other variables in the model, such as POP, indicate whether foreign investors are interested in consumer demand (the market seekers motive). In this case, the increase in POP of one p.p. increases FDI by $0.018 \%$. This influence is rather minor though it is still fairly statistically relevant with $t$ ratio equal to 1.77. Also BERD, which expresses the expenditures of enterprises on R\&D per inhabitant, has a relatively large chance of entering the model (PIP equal $80 \%$ ). The impact of this variable is negative, which could suggest that investments tend to go to those industries where expenditures are relatively low, and thus the technology that is transferred may effectively contribute to improvements. It could also mean that investments flow less often to industries where enterprises invest in innovation. It should be noted, however, that these flows are responsible for absorptive capacities of local enterprises, and thus their ability to implement new, more efficient solutions in developed countries that could be potentially transferred via FDI channels (Makieła, Ouattara, 2018). The positive estimate of HICP (Harmonised Indices of Consumer Prices) seems somehow surprising at first. However, the reader should note that this result is likely driven by changes over time in the analysed panel of industries. The lack of significance of the PRS_AVG parameter estimate, which expresses the investment risk of the host country, may be related to a relatively low dispersion of this phenomenon in the analysed sample. Also, given the fact that the V4 coun- 
tries differ quite significantly, the relatively low probability of inclusion for the variable that expresses market OPENNESS is somewhat surprising at first. However, the reader should note that the V4 economies do share some similarities (EU members, close geography and geopolitics), which could be decisive in rendering variables such as PRS_AVG or OPENNESS statistically insignificant.

To conclude, the obtained results (i.e. the positive and significant parameter of $T F P_{t-1}$ ) support our hypothesis about a positive and statistically significant relationship between productivity and FDI in the V4 economies. Thus, at an industry level, we argue that including productivity of the host country is an important factor in analysing foreign investors' decision-making with respect to FDI. Our results suggest that including TFP as an explanatory variable is justified (not just at the theoretical level) and allows for a better understanding of the international capital flows.

\section{Conclusions}

The results obtained show a positive and robust relationship between productivity and FDI in the host industry, which means that foreign investors pay attention to the observed productivity gains of the target (i.e. host) industry they want to invest in. This confirms the initial hypothesis about a positive relationship between the accumulation of FDI and total factor productivity (see e.g.: Lacina, Strelec, 2008). Since it is unreasonable to postulate that economic activity in a given year has an immediate consequence for investors' decisions as regards FDI (due to a delay in business planning and decision-making), we have considered lagged TFP. There is no unanimous agreement in the literature about the lag of TFP that should be used. Stancik (2007; 2009), for example, notes that in the Czech Republic the increase in production sold is determined by variables lagged even up to 3 years for horizontal, backward and forward investments. That is why, we have implemented Bayesian model averaging (BMA) and considered up to the third lag of TFP. As it turns out, the first lag is the best choice in terms of model fit and the related posterior inclusion probability (PIP). This would indicate that investors tend to consider the latest observed productivity when deciding on their investments. The relationship between FDI and productivity presented in this study should not be surprising. Recent studies also suggest a positive relationship between FDI and labour productivity, which is a part of the TFP considered here (see e.g.: Boghean, State, 2015). Furthermore, Su et. al (2018) have analysed the V4 countries post-EU accession and identified a significant relationship between FDI and high-skilled labour force.

Since the literature is inconclusive with respect to the exact list of FDI determinants, we have also employed BMA in this regard. As it turns out, there is only 
a handful of robust stimulants of FDI to the V4 economies. Similarly to Blonigen and Piger (2014), we find that variables with high inclusion probabilities include traditional gravity variables such as market size. Other significant determinants are human resources, $R \& D$ expenditures, population and changes in prices over time. There is little support for variables such as trade openness and host-country institutions in the case of V4. Our results support an earlier study by Wach and Wojciechowski (2016) concerning FDI determinants in the Visegrad countries which indicates that market and efficiency seeking motives are dominant in the case of decisions made by investors from the "old" EU.

To conclude, the empirical literature about FDI determinants is vast and sometimes contradictory. These contradictions may arise because (i) researchers tend to use different modelling techniques which usually do not fully account for model uncertainty, or due to the fact that (ii) the FDI and economic growth interaction is often treated in one dimension (i.e. as a single equation problem). Based on the proposed model and the aforementioned BMA technique, we have managed to account for modelling uncertainty and established a sound link between inward FDI stock and several of its stimulants, one of which is the first-lag productivity. This link is confirmed for the V4 economies at an industry level. More research based on data from other economies is required to confirm generality of our findings. This, however, requires industry level data which are not easy to come by.

\section{References}

Antonakakis N., Tondl G. (2015), Robust determinants of OECD FDI in developing countries: Insights from Bayesian model averaging, "Cogent Economics \& Finance", vol. 3(1).

Albaum G., Duerr E., Strandskov J. (2002), International Marketing and Export Management, $4^{\text {th }}$ Edition, Financial Times Prentice Hall, Harlow.

Blonigen B.A., Piger J. (2014), Determinants of foreign direct investment, "Canadian Journal of Economics", no. 47(3), pp. 775-812.

Boghean C., State M. (2015), The Relation between Foreign Direct Investments (FDI) and Labour Productivity in the European Union Countries, "Procedia Economics and Finance", vol. 32, pp. 278-285.

Chowdhury A., Mavrotas G. (2005), FDI and Growth: A Causal Relationship, WIDER Working Paper Series, no. 25.

Cieślik A. (2017), Ewolucja teorii bezpośrednich inwestycji zagranicznych. Przeglad wybranej literatury przedmiotu, [in:] M. Maciejewski, K. Wach (eds.), Handel zagraniczny i biznes międzynarodowy we współczesnej gospodarce, Uniwersytet Ekonomiczny w Krakowie, Kraków, pp. 171-189.

Dunning D.H., Lundan S. (2008), Institutions and the OLI Paradigm of the Multinational Enterprise, "Asia Pacific Journal of Management", no. 25, pp. 573-593.

Eicher T., Helfman L., Lenkoski A. (2011), Robust FDI Determinants: Bayesian Model Averaging in the Presence of Selection Bias, "Journal of Macroeconomics", no. 34(3), pp. 637-651.

Estrin S., Bevan A.A. (2004), The determinants of foreign direct investment into European transition economies, "Journal of Comparative Economics", no. 32(4), pp. 775-787. 
Filippini M., Greene W. (2016), Persistent and transient productive inefficiency: a maximum simulated likelihood approach, "Journal of Productivity Analysis", no. (45)2, pp. 187-196.

Karaszewski W. (2004), Bezpośrednie inwestycje zagraniczne. Polska na tle świata, Wydawnictwo Dom Organizatora, Toruń.

Lacina L., Strelec S. (2008), The Impact of Foreign Direct Investment on the Economic Growth in the Czech Republic, "Acta Universitatis Lodziensis. Folia Oeconomica", no. 233, pp. 19-28.

Leamer E.E. (1983), Let's Take the Con Out of Econometrics, "American Economic Review", no. 73 , pp. 31-43.

Ley E., Steel M.F.J. (2009), On the Effect of Prior Assumptions in Bayesian Model Averaging with Applications to Growth Regression, "Journal of Applied Econometrics", no. 24, pp. 651-674.

Luca G. De, Magnus J.R. (2011), Bayesian model averaging and weighted-average least squares: Equivariance, stability and numerical issues, "The Stata Journal”, no. 11(4), pp. 518-544.

Makieła K. (2017), Bayesian Inference and Gibbs Sampling in Generalized True Random-Effects Models, "Central European Journal of Economic Modelling and Econometrics", no. 9, pp. 69-95.

Makieła K., Ouattara B. (2018), Foreign Direct Investment and Economic Growth: Exploring the Transmission Channels, "Economic Modelling", no. 72, pp. 296-305.

Nicolini M., Resmini L. (2010), Which firms create them and which firms really benefit? FDI spillovers in new EU member states, "Economics of Transition", no. 18(3), pp. 487-511.

Próchniak M., Witkowski B. (2012), Konwergencja gospodarcza typu $\beta$ w świetle bayesowskiego uśredniania oszacowań, „Bank i Kredyt”, no. 43(2), pp. 25-58.

Przybylska K. (2001), Determinanty zagranicznych inwestycji bezpośrednich $w$ teorii ekonomicznej. Empiryczna weryfikacja czynników lokalizacji zagranicznych inwestycji bezpośrednich w Czechach, Polsce i na Wegrzech, Postdoctoral thesis, Akademia Ekonomiczna w Krakowie, Kraków.

Różański J., Socha B. (2017), Selected Determinants of Foreign Direct Investment Inflow in Manufacturing Industry in Poland, "Annales Universitatis Mariae Curie-Skłodowska. Sectio H", vol. $\mathrm{LI}(6)$, http://dx.doi.org/10.17951/h.2017.51.6.357.

Rymarczyk J. (2004), Internacjonalizacja i globalizacja przedsiębiorstwa, Wydawnictwo Naukowe PWN, Warszawa.

Sala-i-Martin X., Doppelhofer G., Miller R. (2004), Determinants of Long-Term Growth: A Bayesian Averaging of Classical Estimates (BACE) Approach, "American Economic Review", vol. 94, no. 4, pp. 813-835.

Siddique H.M.A., Ansar R. Naeem M.M., Yaqoob S. (2017), Impact of FDI on Economic Growth: Evidence from Pakistan, "Bulletin of Business and Economics", no. 6(3), pp. 111-116.

Stancik J. (2007), Horizontal and Vertical FDI Spillovers: Recent Evidence from the Czech Republic, "CERGE Working Papers", no. 340.

Stancik J. (2009), FDI Spillovers in the Czech Republic: Takeovers vs Greenfields, "Economic Papers European Communities".

Su W., Zhang D., Zhang C., Abrhám J., Simionescu M., Yaroshevich N., Guseva V. (2018), Determinants of foreign direct investment in the Visegrad group countries after the EU enlargement, "Technological and Economic Development of Economy", no. 24(5), pp. 1955-1978, https:// doi.org/10.3846/tede.2018.5487.

Tsionas M., Kumbhakar S. C. (2014), Firm Heterogeneity, Persistent and Transient Technical Inefficiency: A Generalized True Random-Effects model, "Journal of Applied Econometrics", no. 29(1), pp. 110-132.

Upper Saddle River: Pearson Prentice Hall

Wach K. (2012), Europeizacja małych i średnich przedsiębiorstw: rozwój przez umiędzynarodowienie, Wydawnictwo Naukowe PWN, Warszawa. 
Wach K. (2016), Motywy internacjonalizacji przedsiębiorstw w branży high-tech: wstępne wyniki badań sondażowych, "Przedsiębiorczość i Zarządzanie", t. XVII, z. 10, cz. 1, pp. 99-107.

Wach K., Wojciechowski L. (2014), The factors of outward FDI from V4 countries from the perspective of the EU and the EMU membership: A Panel Gravity Model Approach, "Acta Universitatis Lodziensis. Folia Oeconomica", no. 5(307), pp. 163-176.

Wach K., Wojciechowski L. (2016), Determinants of inward FDI into Visegrad countries: empirical evidence based on panel data for the years 2000-2012, "Economics and Business Review", no. 2(16), pp. 34-52.

Wawrzyniak D. (2017), Rynek pracy a bezpośrednie inwestycje zagraniczne w krajach Europy Środkowo-Wschodniej, "Gospodarka Narodowa", no. 1(287), pp. 53-68.

Wojciechowski L., Lubacha-Sember J. (2014), Uwarunkowania przepływu polskich bezpośrednich inwestycji zagranicznych do krajów Unii Europejskiej. Model grawitacyjny z wykorzystaniem danych panelowych, "Ekonomia Międzynarodowa", no. 7, pp. 136-149.

Yannopoulos G.N. (1990), Foreign Direct Investment and European Integration: the Evidence from the Formative Years of the European Community, "Journal of Common Market Studies", no. XXVIII, pp. 235-259.

Yannopoulos G.N. (2011), Defensive and Offensive Strategies for Market Success, „International Journal of Business and Social Science", vol. 2, no. 13, pp. 1-12.

Yip G. S., Hult G.T.M. (2012), Total global strategy, $3^{\text {rd }}$ ed., Pearson Prentice Hall, Upper Saddle River.

\section{Appendix: Bayesian model averaging}

The latter equation in (1), on which we focus in this paper, is estimated using Bayesian model averaging. The technique is particularly useful whenever the underlying theory lacks sufficient information as to the exact parametric specification of the model. In our case, it is the multiplicity of potential determinants of FDI inflow depicted in Section 3.2 - surely not all of them relevant for investing in the V4 economies. There are many FDI theories, indicating the key factors that implicate the phenomenon. This, in turn, gives us numerous potential factors along with their measurement problems and legitimacy of operationalising as model variables in specific cases. Ley and Steel (2009) consider the problem of variable selection in linear regressions and note that Bayesian averaging has become an important tool in empirical research whenever we face a significant number of potential regressors and a relatively limited number of observations as is the case in this study. Generally, the idea of Bayesian model averaging is to consider all models that can be estimated using a particular (sub)set of explanatory variables (taking into account all possible combinations). Bayesian inference allows us to (i) select the most probable combination of explanatory variables from a large set, (ii) calculate the explanatory power of all models, (iii) construct model rankings, and (iv) pool inference on any quantity of interest where posterior probabilities are treated as weights. Bayesian model averaging - BMA, also known as combining knowledge or inference pooling, is a tool used to solve the problem of uncertainty in the adequate selection of variables of the econometric model. Assuming that there are $K$ potential explanatory variables, there are $2^{\mathrm{K}}$ potential model combina- 
tions. In short, BMA relies on estimation $2^{\mathrm{K}}$ OLS regressions, which are then aggregated using Bayesian methods. Due to this, it is possible to determine the posterior probability of a given model and the probability of an inclusion of a given variable in the model. BMA can also be used to choose the model specification. The BMA method is based on the posterior probability calculation for the $k$-model $P\left(M_{k} \mid X\right)$, conditional probability, which depends on the a priori probability regarding model $k-P\left(M_{k}\right)$ and the boundary density of the observation vector $k P\left(X \mid M_{k}\right)$. $P\left(M_{k} \mid X\right)$ we calculate using (3)

$$
P\left(M_{i} \mid X\right)=\frac{P\left(X \mid M_{i}\right) P\left(M_{i}\right)}{\sum_{j=1}^{2^{K}} P\left(X \mid M_{j}\right) P\left(M_{j}\right)} .
$$

One of the first methods of this type was EBA (extreme bound analysis) proposed by Leamer (1983). In order to indicate "robust" relations, he proposed to estimate all possible to create $2^{\mathrm{K}-1}$ linear models and point out the lowest and the largest values of the parameter estimates at a given variable based on the estimated models. Leamer (1983) suggested acknowledging the "robust" relationship between these explanatory and explanatory variables, whenever the sign (minimum and maximum) of the parameter at a given variable is the same.

Although Bayesian averaging has been known for many decades, it gained great popularity in applied research after publishing the work of Sala-i-Martin, Doppelhofer and Miller (2004). The authors presented a simplified version of the technique, the so-called BACE (Bayesian Averaging of Classical Estimates), suitable for the case of estimation of linear models using OLS. Utilised by, e.g.: Sala-i-Martin, Doppelhofer and Miller (2004) Bayesian averaging of BACE estimates largely solves the aforementioned problems by avoiding uncertainty associated with the selection of correct variables and specifications. This paper uses the BMA procedure described in De Luca and Magnus (2011) calculated in the Stata 14 package.

\section{Determinanty bezpośrednich inwestycji zagranicznych w krajach Grupy Wyszehradzkiej}

Streszczenie: Celem niniejszego artykułu jest określenie determinant akumulacji zagranicznych inwestycji bezpośrednich (FDI) w krajach Grupy Wyszehradzkiej. Teoria zakłada, że FDI jest motywowana głównie chęcią pozyskiwania rynku i poprawy efektywności gospodarowania. Ponieważ zagraniczni inwestorzy szukają sprawnego i relatywnie taniego środowiska biznesowego, można przyjąć założenie, że produktywność jest jednym z kluczowych czynników przyciągających inwestycje zagraniczne. W celu weryfikacji takiego założenia sformułowano model bazujący na systemie dwóch równań: pierwszego dla produkcji, szacującego produktywność, oraz drugiego dla FDI, mającego na celu przeanalizowanie wpływu produktywności na FDI. Aby sprawdzić rzetelność badanej interakcji, 
wzięto również pod uwagę czynniki makroekonomiczne i instytucjonalne. Badanie przeprowadzono na 13 sektorach przemysłowych NACE w krajach V4 w latach 2004-2013. Wyniki wskazują na istotny związek między FDI i produktywnością, jak również na to, że rozmiar rynku, jakość (i ilość) siły roboczej, wydatki na B+R oraz zmiany cen w czasie są istotnymi determinantami FDI na poziomie przemysłu.

Słowa kluczowe: bezpośrednie inwestycje zagraniczne, Grupa Wyszehradzka, bayesowskie uśrednianie modeli

JEL: F21, O47, C11

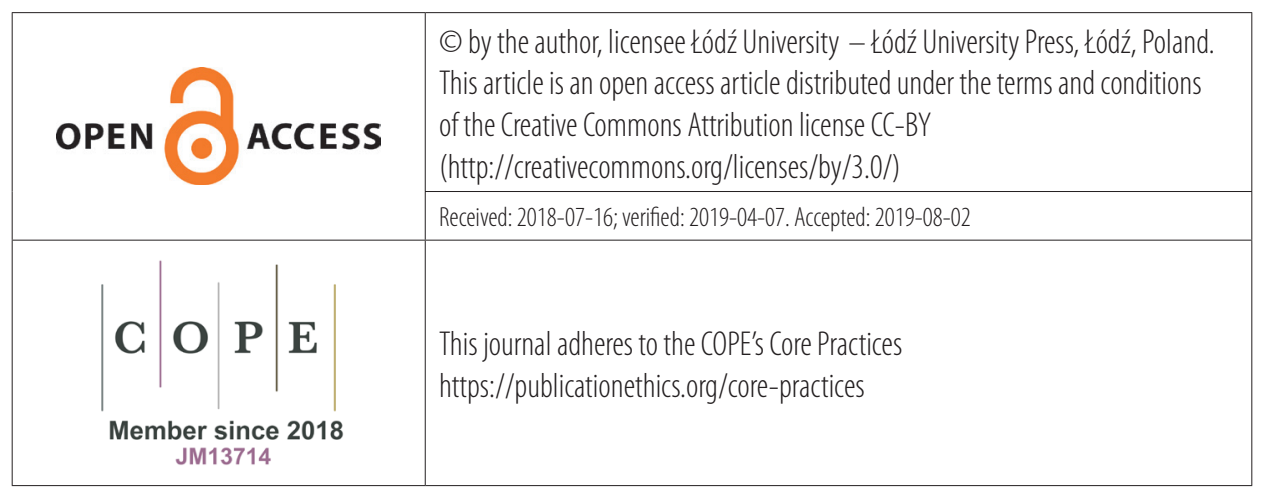

